\title{
Learning environment and graduates' transition period
}

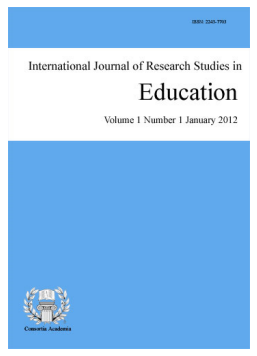

Patria, Bhina $\measuredangle$

Faculty of Psychology, Universitas Gadjah Mada, Yogyakarta, Indonesia (patria@ugm.ac.id) International Centre for Higher Education Research (INCHER-Kassel), University of Kassel, Germany

\section{Abstract}

This study investigated the model of learning environment and graduates' transition period from higher education to employment. The responses to a questionnaire of 13,532 graduates from eight countries were analyzed using a structural equation modeling approach. The tested model indicates a close fit based on Chi-square $=233.34, d f=10, \mathrm{p}<0.001$; Chi-square $/ d f=$ 23.33; $C F I=0.984 ; R M S E A=0.042$. The results showed that learning environment, as composite of structure of courses, institutional support, infrastructure, student activity, and research, affects graduates competencies. Graduates' competencies were shown to have a significant relationship with graduates' transition period in term of job search duration. The higher graduates' competencies are; the shorter the transition period will be. In addition, transition period is also influenced by study abroad experience. Graduates with experience abroad reported to have a shorter period of job search.

Keywords: learning environment; transition period; study abroad; competencies 


\section{Learning environment and graduates' transition period}

\section{Introduction}

Transition periods are often seen as uncomfortable situations because one has to leave their state of security and move into vague and abstract conditions (Fremerey, 2006). Transition from higher education to employment shares the same characteristics with other transition process (Allen \& Van Der Velden, 2007). This situation is often described as a stressful condition for students because it has a big impact on the future career. On one side graduates are receiving pressure to get employment as soon as possible, but on the other side they have to be selective in choosing employment which is in accordance with their criteria (e.g. related to field of study, salary, benefit). A lot of problems will occur in this period, not only for average students but also for highly talented students, if they are not well prepared.

The concept of transition period comes from the anthropological literature on "rite de passage" or rites of passage, which described as the condition where previously dependent juveniles in a community/tribe step into the independent adults' world, an event celebrated in a highly ritualized ceremony (Hannan \& Werquin, 2001). In previous era, the community member perceived the transition period as a simple and stable event which, in current modern times, no longer applies (Hannan \& Werquin, 2001).

In modern industrialized cultures, transition is more complex and a lot of conditions affect the process. The transition period from higher education to work, which in the past was defined simply as an intermediate status between full-time schooling and full-time employment, no longer reflects the current situation (Teichler, 1999). The transition period becomes more complex and difficult. Longer periods of unemployment, lengthening of job search periods, job shifts and job mismatches are some of the problems in the transition period (Allen \& Van Der Velden, 2007; OECD, 2000; Teichler, 1999).

The complexity of the transition period can be explored in depth when discussing within the frame work of the relationship between higher education and work. Table 1 provides the complete preview of the relationship between higher education and work.

\section{Table 1}

Relationships between Higher Education and Work

\begin{tabular}{|c|c|c|}
\hline $\begin{array}{l}\text { Dimensions of higher education } \\
\text { relevant to work }\end{array}$ & $\begin{array}{l}\text { Linkages between higher } \\
\text { education and work }\end{array}$ & $\begin{array}{l}\text { Dimensions of work relevant } \\
\text { to higher education }\end{array}$ \\
\hline $\begin{array}{ll}\text { - } & \text { Qualitative and structural } \\
\text { developments }\end{array}$ & 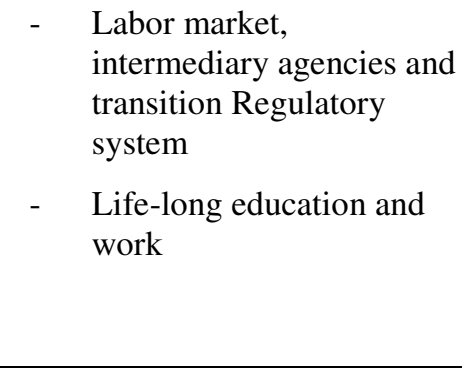 & $\begin{array}{ll}\text { - } & \text { Employment } \\
\text { - } & \text { Career } \\
\text { - } & \text { Work tasks and } \\
& \text { requirements } \\
- & \text { Profession } \\
-\quad & \text { Quality of work and } \\
\text { employment }\end{array}$ \\
\hline
\end{tabular}

Note. Source: Brennan, et al., (1996, p. 2).

In the linkages between higher education and work aspects, labor market situation, intermediary agencies, and transition regulatory systems play important roles. The smoothness of the transition process for graduates is influenced by the involvement of the university in the placement process. The development of career-centers is already a common practice in universities to help graduates survive in the transition period. 
Improving the relationship between higher education and work not only requires better attention to the aspect of the linkages between higher education and work, but also attention to the dimensions of higher education relevant to work. Themes of the dimensions of higher education relevant to work - such as quantitative and structural developments, curricula, training and socialization, educational provisions, and students' options should also be considered.

The discussion in this study focuses on analyzing the transition period from the aspect of dimensions of higher education relevant to work in terms of the relationship between learning environment and graduates' transition period. It is important to note that this study is not offering a "quick fix" or a recipe to overcome the problems in the transition from higher education to work. Rather, this paper tries to give one perspective: that improving one dimension of higher education relevant to work could have an impact on graduates' transition period from higher education to the world of work.

\subsection{Learning environment and graduates competencies}

Biggs' (1989) framework on the concept of learning processes is comprised of three factors (3P): the learning environment and student characteristics (presage), students' approach to learning process (process), and learning outcomes (product). The presage factor exists prior to learning which refers to a student's certain characteristics, abilities, expectations and motivation for learning and conceptions of what university learning is about. The learning environment or the teaching context contains factors which are under the teacher's and institution's control: course structure and content; methods of teaching and assessment; and learning climate. The presage factor influences students in adopting a particular approach to learning. The outcome of learning is determined by the approach adopted.

A similar model was proposed by Wahlberg (as cited in Vermeulen, 2006). The educational productivity model states that there are three general sources that influence students' learning outcomes: the characteristics of the student himself; the characteristics of the learning environment; and contextual influences of a social nature.

Lizzio, Wilson and Simons (2002) found that learning environment at university was a stronger predictor of learning outcomes than prior achievement at school. Learning environment was a significant predictor of students' levels of generic skill development. Here, generic skills or competencies refer to the process skills which help students to effectively apply the content or subject skills learnt in higher education to work environments. Furthermore, Lizio et al. (2002) pointed out that these skills (also mentioned as key skills, core competencies, or generic attributes) include problem-solving, analytical skills, teamwork and ability to plan work.

A similar result was also reported by Vaatstra and De Vries (2007) who investigated the effect of activating learning environment on graduates competencies. Their study reported that graduates from activating learning environments assess themselves as having more generic and reflective competencies than graduates who studied in conventional learning environments. Active learning is often contrasted to the conventional or traditional lecture where students passively receive information from the instructor. The term active learning has been applied to situations where students engaged in the learning process. In short, students must do more than just listen. Students must actively involved and engage in such higher-order thinking task (e.g. analysis, synthesis, and evaluation) (Bonwell \& Eison, 1991).

It is expected that employer will assess graduates' competencies in selecting new employees, therefore graduates with higher competencies expected to be noticed by the employer and have a shorter transition period than their colleagues who have lower competencies.

\subsection{Study abroad and graduates' transition period}

The benefit of study abroad usually analyzed in five spheres, include foreign language proficiency, cultural 
enrichment, personal development, and professional impact (Carlson, Burn, Useem, \& Yachimowicz, 1990; Doherty, Dickmann, \& Mills, 2010; Freed, 1998; Kinginger, 2011; Maiworm \& Teichler, 1996, 2002; Opper, Teichler, \& Carlson, 1990; Van Hoof \& Verbeeten, 2005).

Several studies reported that study abroad has a positive effect on shortening graduates' transition periods. Opper, Teichler, and Carlson (1990) pointed out that study abroad experience had been helpful (43\%) or even very helpful (23\%) for graduates in finding their first job. Jahr and Teichler (2002) reported that study abroad experience is regarded as a help for shortening the transition period. Bracht, Engel, Janson, Over, Schomburg, and Teichler (2006) also confirm that while study abroad experience is not necessarily a boost for a "high-flying" career, it is regarded as a help for transition from higher education to work. Studies on employers' perspectives also showed a similar result: employers believed that graduates with international experience have higher competencies (Messer \& Wolter, 2007).

\subsection{Research Questions}

Several research questions were addressed in this study. Does learning environment influence graduates' competencies? Do graduates' competencies influence graduates' transition period? Is transition period influenced by study abroad experience? And the most important is: what should the university do in order to prepare graduates facing the transition period?

Based on the aforementioned theoretical approach, it is expected that learning environment will affect graduates' competencies and that the higher graduates' competencies are, the shorter the transition period will be. It is expected that study abroad experience will influence the transition period directly and through graduates' competencies. Figure 1 shows the hypothesized model of the relationship between the academic learning environments, graduates' competencies, study abroad experience and graduates' transition period.

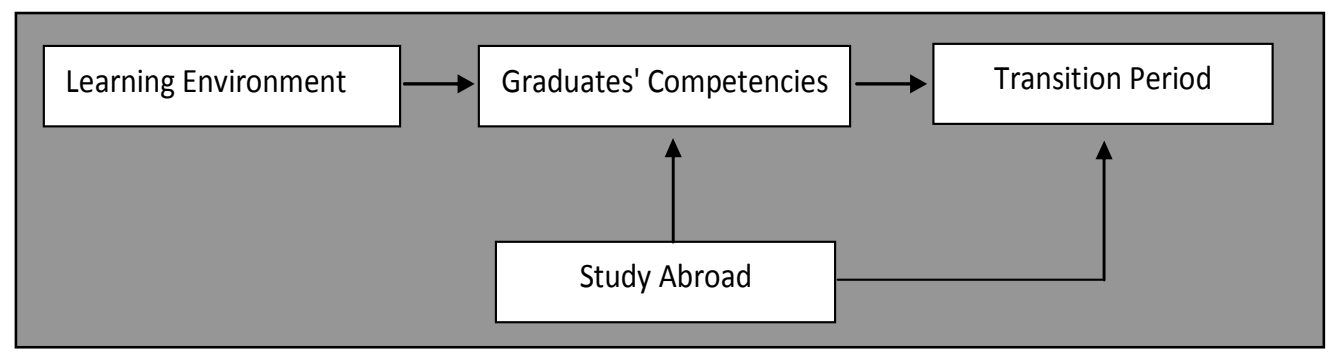

Figure 1. Hypothesized model of the relationship between learning environment and graduates' transition period

\section{Method}

\subsection{Subjects}

The data used in this study was based on the data collected in CHEERS (Careers after Higher Education: a European Research Study) project. CHEERS was a research project conducted from 1998 to 2000. This survey covered more than 36,000 graduates from 12 countries, i.e. Italy (IT), Spain (ES), France (FR), Austria (AT), Germany (DE), the Netherlands (NL), the United Kingdom (UK), Finland (FI), Sweden (SE), Norway (NO), Czech Republic (CZ), and Japan (JP). The study focused on the relationship between higher education and employment four years after graduation.

Several themes were addressed in the CHEERS survey: socio-biographic background, study paths, transition from higher education to employment, early career, links between study and employment, job satisfaction and 
perspectives of the graduates on higher education (WZ1, 2000).

Graduates who participated in the CHEERS survey were young graduates with four years since their graduation. The total data set shows that gender presentation was equal between male (49.7\%) and female $(50.1 \%)$ graduates. The gender composition in each country was also fairly equal. Table 2 shows graduates' gender composition breakdown by countries in CHEERS data. Graduates' age composition was ranging with an average of 30.4 years old $(S D=5.19, M d n=29)$.

\section{Table 2}

Gender by Country (percent) in CHEERS Data

\begin{tabular}{|c|c|c|c|c|c|c|c|c|c|c|c|c|c|}
\hline \multirow[b]{2}{*}{ Items } & \multicolumn{13}{|c|}{ Country } \\
\hline & IT & ES & FR & AT & $\mathrm{DE}$ & NL & UK & FI & SE & NO & $\mathrm{CZ}$ & $\mathrm{JP}$ & Total \\
\hline Male & 47 & 43 & 49 & 55 & 59 & 49 & 42 & 44 & 42 & 41 & 56 & 68 & 50 \\
\hline Female & 53 & 57 & 51 & 45 & 41 & 51 & 58 & 56 & 58 & 59 & 44 & 32 & 50 \\
\hline Total & 100 & 100 & 100 & 100 & 100 & 100 & 100 & 100 & 100 & 100 & 100 & 100 & 100 \\
\hline Count (n) & (3102) & (3020) & (3051) & (2307) & (3486) & (3052) & (3442) & (2664) & (2629) & (3329) & (3092) & $(3421)(3$ & 36596) \\
\hline
\end{tabular}

Note. Question I1: Gender

Graduates in CHEERS data means those who had finished their study and were awarded the first degree or leaving certificate based on between three and six years of study. In order to summarize the diversity of type of study in each country, the type of degree obtained by the graduates were classified into two levels which were based on the length of time needed to finish studying. Short duration of study (A) was equal to a bachelor degree, while long duration of study (B) was equal to a master degree. From the total data set, $39.7 \%$ of graduates completed short duration study degrees and $60 \%$ of graduates obtained long duration study degrees. Table 3 shows the type of degree obtains by the graduates break by country in CHEERS data. The data set also addressed a broad range of fields of study and higher education institutions. This was to ensure that the variance of different fields of study and different type of institutions were well represented.

\section{Table 3}

Types of Degree Obtained by Country (percent) in CHEERS Data

\begin{tabular}{|c|c|c|c|c|c|c|c|c|c|c|c|c|c|}
\hline \multirow[b]{2}{*}{ Items } & \multicolumn{13}{|c|}{ Country } \\
\hline & IT & $\mathrm{ES}$ & FR & AT & DE & NL & UK & FI & SE & NO & $\mathrm{CZ}$ & JP & Total \\
\hline $1 \mathrm{~A}$ (bachelor) & 0 & 31 & 42 & 0 & 37 & 63 & 94 & 0 & 0 & 65 & 9 & 100 & 40 \\
\hline 2 B (master) & 100 & 69 & 58 & 100 & 63 & 37 & 6 & 100 & 100 & 35 & 91 & 0 & 60 \\
\hline Total & 100 & 100 & 100 & 100 & 100 & 100 & 100 & 100 & 100 & 100 & 100 & 100 & 100 \\
\hline Count (n) & (3102) & (3016) & (3051) & (2312) & (3506) & (3083) & $(3460)$ & (2675) & (2634) & (3329) & (3092) & (3394) & (36655) \\
\hline
\end{tabular}

Note. Question B1D: Please, provide information about all higher education courses you have ever taken (include part-time, post graduate, and courses not completed). D. Kind of degree earned.

\subsection{Criteria for inclusion in the study}

In this study, the data were first filtered by the types of degree obtained by the graduates. Only graduates with short duration of study (bachelor) were selected in the data set. This process changes the composition of countries in the data set. Some countries (i.e. Italy, Austria, Finland, and Sweden) were excluded from the data set because they did not have graduates with short duration of study in their data set.

The data set was also filtered by graduates' response to the learning environment question of CHEERS questionnaire. A missing value or non-response from the graduates was excluded from the data analysis. The reason is that missing value might reduce the power of statistical analysis. The number of respondents in this study, after being filtered by degree obtained and non-response was 13,532 respondents. This final data set was 
Patria, B.

comprised of an equal gender distribution: $50 \%$ males and 50\% females (see Table 4 for details by country). The composition of graduates' fields of study can be observed in Table 5.

Table 4

Gender by Country (percent)

\begin{tabular}{|c|c|c|c|c|c|c|c|c|c|}
\hline \multirow[b]{2}{*}{ Items } & \multicolumn{9}{|c|}{ Country } \\
\hline & ES & FR & $\mathrm{DE}$ & NL & UK & $\mathrm{NO}$ & $\mathrm{CZ}$ & JP & Total \\
\hline 1 Male & 32 & 45 & 66 & 50 & 42 & 34 & 54 & 67 & 50 \\
\hline 2 Female & 68 & 55 & 34 & 50 & 58 & 66 & 46 & 33 & 50 \\
\hline Total & 100 & 100 & 100 & 100 & 100 & 100 & 100 & 100 & 100 \\
\hline Count (n) & (890) & (1210) & (1226) & (1822) & (2923) & (1893) & (269) & (3264) & (13498) \\
\hline
\end{tabular}

Note. Question I1: Gender

Table 5

Field of Study by Country (percent)

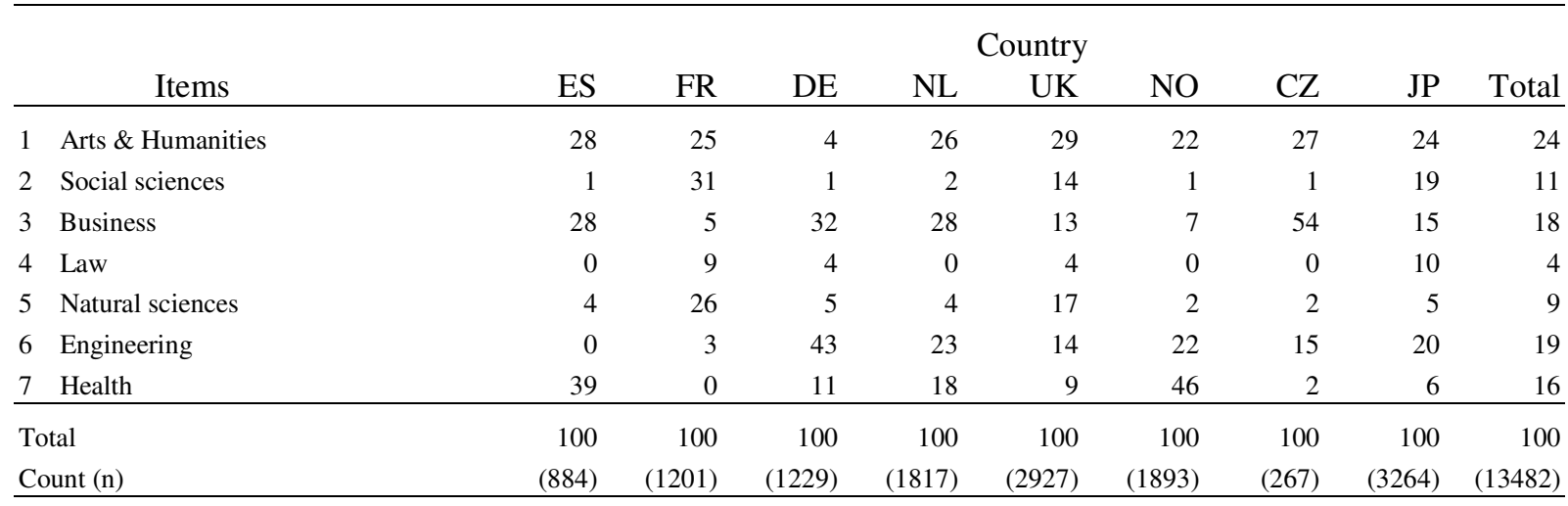

Note. Question B1: Please, provide information about all higher education courses you have ever taken (include part-time, post graduate, and courses not to completed).

\subsection{Variables and Instruments}

\subsubsection{Learning environment}

Question B9 from the CHEERS questionnaire measured the quality of learning environment perceived by the graduates. The graduates were asked to rate their responses on study provision and study condition they have experienced in their course of study. The scale ranges from 1 (Very bad) to 5 (Very good). Factor analysis was conducted to reduce the complexity of the data. This analysis yields to five factors of learning environment: structure of courses, institutional support, infrastructure, student activity, and research. Table 6 presents the 18 attributes of question B9 with the mean score and standard deviations listed.

From the result of factor analysis, five new variables were created using the method of item parceling. This method is created by Cattel (1956) which is summing or averaging together two or more items and using the result as the basic unit of analysis. In this study the factor variable of learning environment was created by averaging all items which belong to one specific factor. This means, for example, that the variable STRUC which is representing structure of course factor was created by averaging graduates responses in four variables: opportunity to choose courses and areas of specialization (1); design of degree program (2); variety of courses offered (3); and course content of major (4). The same procedure was used to produce the other variables measuring learning environment (i.e. INST, INFRA, STUDAC, and RESEARCH). 
Table 6

Items Measuring Learning Environment

\begin{tabular}{llc}
\hline \multicolumn{1}{c}{ Items } & Mean & SD \\
\hline Structure of courses (STRUC) & 3.05 & 1.167 \\
Opportunity to choose courses and areas of specialization & 3.24 & 0.922 \\
Design of degree program & 3.38 & 1.006 \\
Variety of courses offered & 3.56 & 0.868 \\
Course content of major & & 0.960 \\
& & 1.111 \\
Institutional support (INST) & 3.11 & 0.908 \\
Academic advice offered in general & 3.27 & 1.051 \\
Assistance/advice for your final examination & 3.21 & 0.938 \\
Testing/grading system & 3.07 & 1.099 \\
Practical emphasis of teaching and learning & 3.17 & 1.000 \\
Teaching quality & & 1.151 \\
Infrastructure (INFRA) & 3.50 & 3.23 \\
Equipment and stocking of libraries & 3.01 & \\
Supply of teaching material & & 1.097 \\
Quality of technical equipment (e.g. PC measuring instruments, etc.) & & 1.095 \\
Student activity (STUDAC) & 2.78 & 1.106 \\
Opportunity of out-of-class contacts with teaching staff & 3.83 & 0.991 \\
Contacts with fellow students & 2.50 & 1.038 \\
Chance for students to have an impact on university policies & 2.59 & 1.304 \\
Provision of work placements and other work experience & & \\
Research (RESEARCH) & 2.22 & \\
Chances to participate in research projects & & \\
Research emphasis of teaching and learning & & \\
\hline
\end{tabular}

\subsubsection{Graduates' competencies}

Question E1 of the CHEERS questionnaire was used as the indicator of graduates' competencies at time of graduation. In question E1 graduates were asked to rate their competencies at the time of graduation. There were 36 items of knowledge, skills and competencies that graduates rated according to their perception. The scale was ranging from 1 (Not at all) to 5 (To a very high extent). Table 7 presents the 36 items on questions E1 with the mean score and standard deviations listed. The grouping of the items in Table 7 was based on the result of factor analysis. Item parceling method was also used in creating a variable that comprises graduates' competencies at time of graduation. This variable was created by summing 36 items in question E1.

\subsubsection{Transition period}

In this study transition period was undergone by the duration of the job seeking period conducted by graduates. Graduates were asked how many months they spent searching (before or after graduation) for their first job after graduation. Graduates were instructed to exclude casual jobs in their calculation. Graduates' duration of job search was varied with an average of 5.29 months $(S D=6.12$; $M d n=3)$.

\subsubsection{Study abroad experience}

Graduates' responses to question B2 in the CHEERS questionnaire were an indication of study abroad experience. Question B2 asked "Did you spend time abroad during the time of your study (in order to work or to study)?" Graduates' responses were re-coded in to a dichotomous variable with $0=$ "No" and $1=$ "Yes". The proportion of graduates who had study abroad experience was small (15\%) compared to those who did not (83, $4 \%)$. 
Patria, B.

Table 7

Items Measuring Graduates' Competencies at Graduation

\begin{tabular}{|c|c|c|}
\hline Items & Mean & SD \\
\hline \multicolumn{3}{|l|}{ Leadership } \\
\hline Leadership & 2.95 & 1.043 \\
\hline Initiative & 3.54 & 0.963 \\
\hline Assertiveness, decisiveness, persistence & 3.40 & 0.994 \\
\hline Taking responsibilities, decision & 3.33 & 1.024 \\
\hline Creativity & 3.32 & 1.033 \\
\hline Negotiating & 2.67 & 1.049 \\
\hline Critical thinking & 3.62 & 0.932 \\
\hline \multicolumn{3}{|l|}{ Personal working skills } \\
\hline Accuracy, attention to detail & 3.56 & 1.016 \\
\hline Time management & 3.32 & 1.039 \\
\hline Power of concentration & 3.77 & 0.892 \\
\hline Working under pressure & 3.43 & 1.102 \\
\hline Reflective thinking, assessing one's own work & 3.48 & 0.963 \\
\hline Learning abilities & 3.90 & 0.845 \\
\hline Working independently & 3.70 & 1.027 \\
\hline Problem-solving ability & 3.53 & 0.900 \\
\hline \multicolumn{3}{|l|}{ Interpersonal skills } \\
\hline Loyalty, integrity & 3.85 & 0.974 \\
\hline Tolerance, appreciating of different points of view & 3.66 & 0.947 \\
\hline Adaptability & 3.73 & 0.915 \\
\hline Working in a team & 3.67 & 1.005 \\
\hline Getting personally involve & 3.68 & 0.957 \\
\hline Fitness for work & 3.49 & 1.043 \\
\hline Manual skill & 3.06 & 1.160 \\
\hline \multicolumn{3}{|l|}{ Field-related knowledge } \\
\hline Field-specific theoretical knowledge & 3.62 & 0.971 \\
\hline Field-specific knowledge of methods & 3.31 & 1.017 \\
\hline Analytical competencies & 3.45 & 0.934 \\
\hline Cross-disciplinary thinking/knowledge & 3.31 & 0.904 \\
\hline Broad general knowledge & 3.55 & 0.869 \\
\hline \multicolumn{3}{|l|}{ Organizational skills } \\
\hline Economic reasoning & 2.73 & 1.102 \\
\hline Applying rules and regulations & 3.07 & 1.042 \\
\hline Planning, co-coordinating and organizing & 3.10 & 1.050 \\
\hline Documenting ideas and information & 3.30 & 1.020 \\
\hline \multicolumn{3}{|l|}{ Special skills } \\
\hline Foreign language proficiency & 2.52 & 1.142 \\
\hline Computer skills & 2.82 & 1.201 \\
\hline Understanding complex social, organizational and technical systems & 2.74 & 1.008 \\
\hline \multicolumn{3}{|l|}{ Basic communication skills } \\
\hline Written communication skill & 3.67 & 0.969 \\
\hline Oral communication skill & 3.55 & 1.004 \\
\hline
\end{tabular}

Note. Grouping of the items was based on the result of factor analysis.

\subsection{Data Analysis}

For testing the model, this study used structural-equation modeling (SEM), also known as analysis of covariance structures, or causal modeling. Unlike multiple-regression-based approaches to estimate structural 
paths, SEM techniques offer the potential to remove measurement error from estimates of structural relationships (Hall, Snell, \& Foust, 1999). Amos (Analysis of moment structures) was the software used to test the model. Amos provides a clear representation of the model in graphical mode and the numeric methods implemented in Amos are among the most effective and reliable available (Arbuckle, 1999).

Amos has several outputs that can be used as criteria for fitting a model. Outputs used in this study were: Chi-square statistic, Comparative fit index (CFI) and the Root mean square error of approximation (RMSEA). CFI and RMSEA were used in addition because Chi-square tends to be significant in a model with a big data set. The cut-off value of 0.95 was used in CFI as suggested by Hu and Bentler (as cited in Vermeulen, 2006). The rule of RMSEA was based on MacCallum, Browne and Sugiwara (1996). RMSEA values less than .05 indicate a close fit; values ranging from .05 to .08 indicate a fair fit; values from .08 to .10 indicate a mediocre fit and values higher than .10 indicate a poor fit. Browne and Cudeck (1993) suggested not to employ a model with RMSEA greater than 0.1 because that would indicate an error of approximation. Beside the whole data set, the model was also tested on control groups which were gender and field of study.

\section{Results}

The results of the tested model were Chi-square $=233.34 ; d f=10 ; p<0.001 ;$ Chi-square $/ d f=23.33 ; C F I=$ $0.984 ; R M S E A=0.042$. This result indicates a close fit based on the criteria by MacCallum, Browne and Sugiwara (1996).

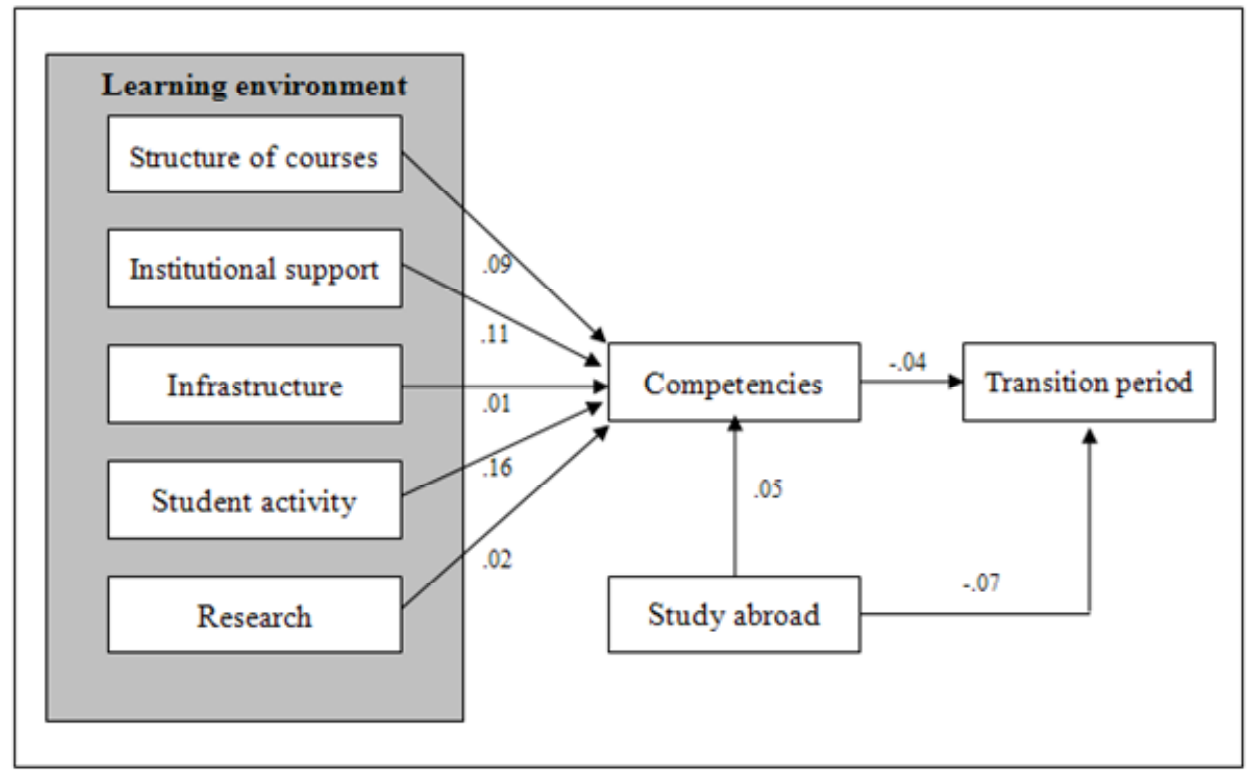

Figure 2. Model of the relationship between learning environment and graduates' transition period

Most of the standardized path coefficients were small, however in the overall model were significant at a 5\% level. The complete standardized regression coefficients can be observed in Table 8 . In the relation to competencies, student activity factor has the highest standardize regression weight $(\beta=.158)$, followed by institutional support $(\beta=.114)$, structure of courses $(\beta=.092)$ and research $(\beta=.022)$. However, the infrastructure factor does not affect students' competencies, since no significant relationship $(\beta=.014 ; p=$ n.s. $)$ between these variables was found in this study.

Initially, analysis was conducted in two data sets controlled for male and female graduates to test the gender influence in the model. However, no differences were found between them. The second controlled group was field of study. This step was necessary to determine the effect of different kinds of fields of study on the fitness of the model. Studies on CHEERS data (e.g. Allen \& Van Der Velden, 2007) showed that field of study was a relevant issue in the study of graduates' transition period. Dolton and Makepeace (1990) also confirmed that 
Patria, B.

professional domain is a relevant issue that affects graduates' future life, for instance in earning difference.

Table 8

Standardized regression coefficients of the model

\begin{tabular}{lcc}
\hline \multicolumn{1}{c}{ Items } & $\beta$ & $p$ \\
\hline Institutional support > Competencies & .114 & .000 \\
Infrastructure > Competencies & .014 & .166 \\
Structure of courses > Competencies & .092 & .000 \\
Research > Competencies & .022 & .030 \\
Student activity > Competencies & .158 & .000 \\
Study abroad > Competencies & .050 & .000 \\
Competencies > Transition period & -.035 & .005 \\
Study abroad > Transition period & -.065 & .000 \\
\hline
\end{tabular}

Table 9 shows that fit indices vary between fields of study. However, the overall fitness parameter across them was similar. Only in the field of law the Chi-square value was not significant.

Table 9

Fit Statistics of the Model by Field of Study

\begin{tabular}{|c|c|c|c|c|c|c|c|}
\hline & Items & $x^{2}$ & $d f$ & $\chi^{2} / d f$ & $\mathrm{n}$ & CFI & RMSEA \\
\hline 1 & Arts \& Humanities & $41.890^{*}$ & 10 & 4.189 & 3013 & .991 & .033 \\
\hline 2 & Social sciences & $47.019 *$ & 10 & 4.701 & 1340 & .976 & .053 \\
\hline 3 & Business & $75.992 *$ & 10 & 7.599 & 2197 & .973 & .055 \\
\hline 4 & Law & $13.700 * *$ & 10 & 1.370 & 584 & .995 & .025 \\
\hline 5 & Natural sciences & $27.508^{*}$ & 10 & 2.750 & 1124 & .988 & .039 \\
\hline 6 & Engineering & $57.163^{*}$ & 10 & 5.716 & 2167 & .981 & .047 \\
\hline 7 & Health & $98.602 *$ & 10 & 9.860 & 2188 & .965 & .064 \\
\hline
\end{tabular}

Note. $* p<0.01 . * * \mathrm{p}=\mathrm{ns}$

Table 10 shows the standardized regression coefficients of the model break by field of study. The parameter estimates differ between each field of study. For the path from institutional support and structure of courses to graduates' competencies, almost all relationships were significant at a 5\% level. Only the relationship between institutional support and competencies in business field of study was not significant.

\section{Table 10}

Standardized Regression Coefficients of the Model by Field of Study

\begin{tabular}{lccccccc}
\hline \multicolumn{1}{c}{ Items } & $\begin{array}{c}\text { Arts \& } \\
\text { Hum }\end{array}$ & $\begin{array}{c}\text { Social } \\
\text { Sciences }\end{array}$ & Business & Law & $\begin{array}{c}\text { Natural } \\
\text { Sciences }\end{array}$ & Engineering & Health \\
\hline Institutional support > Competencies & .085 & .144 & $.016^{*}$ & .312 & .090 & .160 & .110 \\
Structure of courses > Competencies & .110 & .079 & .156 & .135 & .136 & .115 & .073 \\
Research > Competencies & $-.001 *$ & $.030^{*}$ & .086 & $-.087 *$ & $.057 *$ & $.041^{*}$ & $-.003^{*}$ \\
Student activity > Competencies & .165 & .137 & .126 & $.064^{*}$ & .156 & .109 & .181 \\
Study abroad > Competencies & $.018^{*}$ & .085 & .082 & .121 & $.050^{*}$ & .071 & $-.010^{*}$ \\
Competencies > Transition period & $-.025^{*}$ & -.094 & $-.038^{*}$ & $-.081^{*}$ & $-.079^{*}$ & $-.012^{*}$ & $-.047^{*}$ \\
Study abroad > Transition period & -.072 & -.120 & -.088 & $-.104^{*}$ & $-.036^{*}$ & $-.014^{*}$ & -.081 \\
\hline
\end{tabular}

Note. $* p=\mathrm{ns}$

Other relationships were varied; it would be a potential source for further research to find out the reason for this diversity across field of study. The relationship between research factor and competencies was only significant in the field of business. On the other hand, the relationship between student activity factor and competencies was significant in all fields of study except in the field of law. 
The relationship between study abroad experience and other outcome variables (competencies and transition period) was also interesting to look at. The relationship between study abroad and competencies was significant in social science, business, law, and engineering. The relationship between study abroad and transition period was significant in arts and humanity, social science, business and health.

\section{Discussion}

Figure 2 illustrates the relationships of the five factors of learning environment with graduates' transition period. From this model, three main paths were confirmed. First, the learning environment affects graduates' competencies. The standardized path coefficients for these five factors were considered as low correlation. However, most of the relationships were significant at a $5 \%$ level $(p<0.05)$; only the infrastructure factor had no significant effect on graduates competencies $(\beta=.014 ; p=$ n.s. $)$.

The second path was the path from graduates' competencies at time of graduation to graduates' transition period in term of the duration of job search period. The path shows a negative relation which means that the higher graduates' competencies, the less time they had to spend in searching for the first job.

The third path was the path from graduates' study abroad experience to graduates' transition period. This path also shows a negative relation which means that when graduates have study abroad experience they tend to have less waiting period in getting the first job. Moreover, the path from study abroad experience also shows a positive value which means study abroad also influence graduates' competencies in a positive ways. These findings support the aforementioned hypotheses.

The following sections discuss more in depth several issues regarding the relationship between learning environment, graduates' competencies and transition period. The discussion also includes recommendations for universities in preparing graduates for the transition period and limitations of the study.

\subsection{Student activity and graduates' competencies}

Table 8 shows that the student activity factor has the highest estimation to graduates' competencies. With this result, one could find some practical applications. Universities should enhance the student activity factor in order to smooth the transition period. Based on the attributes constructing student activity factor (see Table 6), university should enrich students' out-of-class contacts with teaching staff. Universities should also create a learning environment that encourages peer learning. Furthermore, students should have more independent study in a group-work setting.

Student interaction with others is categorized by Biggs (1989) in two kinds: hierarchical and lateral. Hierarchical involves intensive interaction (one-on-one) with a responsive expert (i.e. professor). This kind or interaction as a mode of teaching and learning is too expensive to implement. However, the lateral interaction which involves interaction with peers is easier and more realistic to implement. Peer teaching forces students to reflect on what they know and share them to their friends. The process of peer teaching will encourage students to practice their communication and social skills. Students also feel more comfortable learning from peer rather than in a hierarchical state.

Biggs (as cited in Finlay \& Faulkner, 2005) also added that peer-directed teaching and learning offer positive impact for students such as the elaboration of knowledge content, the opportunity to develop skills for judging better and worse peer interpretations, and an increasing awareness of the cognitive processes students undergo in arriving at a particular position. The interactions with peer are also more interesting and entertaining for them rather than listening to a lecture from the teacher. Contacts with fellow students also take place in extra-curricular activities. Tchibozo (2007) suggested that extra-curricular activity has a significant influence on the transition process.

Another aspect that should be considered from the student activity factor is institutions' provision of work 
placements. Universities should encourage students to put their theoretical knowledge into practice. A model of internship or practical experience in a real employment condition will help students in improving their competencies. No matter how good a course program designed is, it cannot duplicate the real world experience. Student cannot learn everything in the classroom. They should have the opportunity to apply their theoretical knowledge in practice. This is in accordance with prior a study by Schön (as cited in Vaatstra \& De Vries, 2007) which suggested sending students into the world of practice from the beginning. This is the best way to prepare students for the complex reality of practice, enabling them to learn to deal with unpredictable and conflict situations. Furthermore, Vaatstra and De Vries (2007) added that those students who apply knowledge from different disciplines to realistic problems or cases are better prepared for the workplace than students who have little direct experience of realistic cases.

The last aspect of the student activity factor suggested that student should have more opportunities in influencing university policies. In the frame work of creating a supportive learning environment, the students' point of view should be taken in to account in the process of designing, redesigning and evaluation process. Könings, Brand-Gruwel and van Merrienboer (2005) provide an argument on this topic. Könings et al. (2005) stated that in the process of designing a learning environment, there may be a discrepancy between designers' (institutional) intentions with the learning environment and teachers' conception of learning and teaching. This situation will lead to non effective implementation of the planned method. Teachers and students' perspective on learning process should be involved in the design of the learning environment. A reciprocal relationship between designers, teachers, and students is needed to exchange ideas about learning and perceptions of learning environments. This process will lead to more effective learning environments, which means also more effective learning and eventually better learning outcomes.

\subsection{Institutional support and graduates' competencies}

The second factor that has high influence on graduates' transition period is the institutional support factor (see Table 8). From the institutional support factor approach, universities should support the practical emphasis of teaching and learning process. University support should be focused on the improvement of teaching quality and the availability of academic advice for students.

As mentioned by Lizzio et al. (2002), teaching quality (i.e. good teaching, clear goals and standards, appropriate assessment and emphasis on independence) has the strongest influence both directly and indirectly on learning outcomes. At a deeper analysis it is the component of good teaching (i.e. reciprocally interactive and motivating transactions between teacher and student) which has the strongest influence. Lizzio et al. (2002) further suggested that good teaching is the "place to invest" if one seeks to make difference in students' learning outcomes.

Beside academic advice in general, universities should also improve the assistance for students doing research. Research experience will be an important value for graduates' employment in the future. An evaluation and feedback system should be also carefully considered. Students will greatly improve based on the feedback they receive. Teachers should always respond to students' work with some note of possible improvement areas, not only in written assignments but also in presentations and other work groups. Only in this way can students improve their knowledge and skills.

\subsection{Structure of the course and graduates' transition period}

Structure of the course is the next factor which has influence on graduates' transition period. Universities should design programs and curricula that enable students to develop the competencies they will need in their future life. This means not only developing field-related competencies but also improving generic competencies (e.g. cross-disciplinary thinking; planning; coordinating and organizing; problem solving ability; analytic competencies; learning ability; working independently and working in a team) and reflective competencies (the 
Learning environment and graduates' transition period

knowledge, attitude and skills that show that a person has an understanding of his thoughts and actions).

\subsection{Higher education infrastructure and graduates competencies}

The non significant standardized regression coefficient in the relation between infrastructure factor and graduates' competencies is important to point out. Does this mean that infrastructure factor in this model (facilities in the library, the quality of teaching equipment and laboratories) not important at all? For creating a supportive learning environment, a good infrastructure should be also considered. Good infrastructure such as a well-maintenance library is a must. However, as proposed by Bigg (1989), the learning outcome is not only influenced by facilities supported by the university but also by student characteristics and student approach to learning. The university can have a high-quality infrastructure but if the students have negative characteristics and an inappropriate learning approach, the learning outcomes will also not be optimal. Vermeulen (2006) added that that the quality of the learning environment cannot express itself directly in the career success of its graduates. The behaviors of the students themselves brought on by the learning environment lead to superior academic performance and, through this, to career success.

From the three top factors contributing to graduates' transition period (study activity, institutional support, and structure of the course), problem-based learning (PBL) might be the suitable method in teaching and learning process for universities. The concept of more responsibility on the students' side rather than on the professors' side in PBL enables students to have peer learning experiences. The independent study in work-groups also encourages them to become long-life learners. A characteristic of PBL which enables students to learn by applying theoretical knowledge to authentic or realistic case is another plus value. Research on education (Vaatstra \& De Vries, 2007) suggested that generic and reflective competencies are best acquired in learning environments in which complex practical problems or simulations of such problems occur regularly. Gaining experience through this method is an important condition for proper preparation for future employment.

The concept of student-centered learning (SCL) in PBL is promoting strategic skills that are needed to develop graduates' competencies. This is in accordance with prior studies in problem-based learning (PBL) and graduates competencies. Vaatstra and De Vries (2007) showed that graduates from activating learning environments attribute more generic and reflective competencies to themselves than graduates from conventional learning environments. Patria (2008) also noted that graduates with PBL experience have higher competencies, compared to their colleagues who studied with conventional approach.

\subsection{Limitations of the study}

There are some limitations that should be considered in this study. The non-experimental design of the study is the most obvious limitation. In non-experimental design, the non controlled variable could obstruct the real relation of the hypothesized condition. However, one should also consider that setting an experimental design in a big scale (such as the CHEERS survey) is impossible to do. This is particularly true in a specific topic like learning environment.

With the use of self-rating or self-report data there is always some concern of subjectivity. The respondents might be underestimating or overestimating their response for certain reason. Nevertheless, previous research argues that self-reported measurement can be used as proxies of direct measurement (Vermeulen, 2006).

Future study should consider a more comprehensive measurement in learning environment. In this study, learning environment was measured only from graduates' perception of learning environment. The more objective measurement of learning environment should be taken into account to have deeper understanding of the relationship between learning environment and students' future employment. A future study investigating the model of learning environment, competencies and transition period in different fields and countries would be very interesting. 


\section{Conclusion}

The smoothness of the transition process from higher education to work usually understood by higher education institutions as being influenced by the institution's involvement in the placement process. Therefore, the development of career centre is a common practice among higher education institutions to help smoothing graduates' transition from higher education to the world of work. However, the attention to dimensions of higher education relevant to work also plays important role in preparing graduates for the transition period. This study showed that an attention to learning environment have a positive impact on graduates' transition period. Improvements in the learning environment increase graduates' competencies. Graduates with higher competencies noticed by the employer and eventually hired by employer quicker than their peers with lower competencies.

In addition, this study also showed the effect of study abroad experience on graduates' competencies and transition period. Study abroad experience influences graduates' competencies which in turn help graduates getting their first job.

\section{References:}

Allen, J., \& Van Der Velden, R. (2007). Transition from higher education to work. In U. Teichler (Ed.), Careers of university graduates: Views and experiences in comparative perspectives (pp. 55-77). Netherlands: Springer. <http://dx.doi.org/10.1007/978-1-4020-5926-1_4>

Arbuckle, J. L., \& Wothke, W. . (1999). Amos 4.0 user guide. Chicago: Smallwaters corporation.

Biggs, J. B. (1989). Approaches to the enhancement of tertiary teaching. Higher Education Research \& Development, 8(1), 7-25. <http://dx.doi.org/10.1080/0729436890080102>

Bonwell, C. C., \& Eison, J. A. (1991). Active learning: Creating excitement in the classroom. ERIC Digest [Electronic Version]. ASHEERIC Higher Education Reports The George Washington University, from http://www.oid.ucla.edu/about/units/tatp/old/lounge/pedagogy/downloads/active-learning-eric.pdf

Bracht, O., Engel, C., Janson, K., Over, A., Schomburg, H., \& Teichler, U. (2006). The professional value of ERASMUS mobility. Kassel: INCHER-Kassel.

Brennan, J., Kogan, M., \& Teichler, U. (1996). Higher education and work: A conceptual framework. In J. Brennan, M. Kogan \& U. Teichler (Eds.), Higher education and work (pp. 1-24). Pennsylvania: Jessica Kingsley Publisher.

Browne, M. W., \& Cudeck, R. (1993). Alternative ways of assessing model fit. In K. A. Bollen \& J. S. Long (Eds.), Testing structural equation models (pp. 136-162). Newbury Park, CA: Sage.

Carlson, J. S., Burn, B. B., Useem, J., \& Yachimowicz, D. (1990). Study abroad: The experience of American undergraduates. New York: Greenwood Press.

Cattell, R. B. (1956). Validation and intensification of the Sixteen Personality Factor Questionnaire. Journal of Clinical Psychology, 12(3), 205-214. <http://dx.doi.org/10.1002/1097-4679(195607)12:3<205::AID-JCLP2270120302>3.0.CO;2-0>

Doherty, N., Dickmann, M., \& Mills, T. (2010). Mobility attitudes and behaviours among young Europeans. Career Development International, 15(4), 378-400. < http://dx.doi.org/10.1108/13620431011066259>

Dolton, P. J., \& Makepeace, G. H. (1990). Graduate earnings after six years: Who are the winners? Studies in Higher Education, 15(1), 31-55. <http://dx.doi.org/10.1080/03075079012331377581>

Fremerey, M. (2006). Resistance to change in higher education: Threat or opportunity? In M. Fremerey \& M. Pletsch-Betancourt (Eds.), Prospects of change in higher education: Towards new qualities \& relevance (pp. 217-230). Frankfurt: IKO-Vlg fur Interkult, GW/Transaction Pubs.

Finlay, S.-J., \& Faulkner, G. (2005). Tete a Tete: Reading groups and peer learning. Active Learning in Higher Education the Journal of the Institute for Learning and Teaching, 6(1), 32-45. <http://dx.doi.org/10.1177/1469787405049945>

Freed, B. F. (1998). An overview of issues and research in language learning in a study abroad setting. Frontiers: The Interdisciplinary Journal of Study Abroad, 4(2), 31-60.

Hall, R. J., Snell, A. F., \& Foust, M. S. (1999). Item parceling strategies in SEM: Investigating the subtle effects of unmodeled secondary constructs. Organizational Research Methods, 2(3), 233-256. <http://dx.doi.org/10.1177/109442819923002>

Hannan, D., \& Werquin, P. (2001). Education and labour market change: The dynamics of education to work transitions in Europe. A review of the TSER programme. In P. Descy, M. Tessaring \& E. Centre for the 
Development of Vocational Training (Eds.), Training in Europe: Second report on vocational training research in Europe 2000: Background report (Vol. 3, pp. 91-135). Luxembourg: Office for Official Publications of the European Communities.

Jahr, V., \& Teichler, U. (2002). Employment and work of former mobile students. In U. Teichler (Ed.), ERASMUS in the SOCRATES programme, finding of an evaluation study (pp. 117-135). Bonn: Lemmens.

Könings, K. D., Brand-Gruwel, S., \& Van Merriënboer, J. J. G. (2005). Towards more powerful learning environments through combining the perspectives of designers, teachers, and students. British Journal of Educational Psychology, 75(4), 645-660. <http://dx.doi.org/10.1348/000709905X43616>

Kinginger, C. (2011). Enhancing Language Learning in Study Abroad. Annual Review of Applied Linguistics, 31 , 58-73. <http://dx.doi.org/10.1017/S0267190511000031>

Lizzio, A., Wilson, K., \& Simons, R. (2002). University students' perceptions of the learning environment and academic outcomes: Implications for theory and practice. Studies in Higher Education, 27(1), 27-52. $<$ http://dx.doi.org/10.1080/03075070120099359>

MacCallum, R. C., Browne, M. W., \& Sugawara, H. M. (1996). Power analysis and determination of sample size for covariance structure modeling. Psychological Methods, 1(2), 130-149.

Maiworm, F., \& Teichler, U. (1996). Study abroad and early career: Experiences of former ERASMUS students. London: Jessica Kingsley Publishers.

Maiworm, F., \& Teichler, U. (2002). The student's experience. In U. Teichler (Ed.), Study Abroad. Bonn: Academic Cooperation Association.

Messer, D., \& Wolter, S. (2007). Are student exchange programs worth it? Higher Education, 54(5), 647-663. $<$ http://dx.doi.org/10.1007/s10734-006-9016-6>

OECD. (2000). From initial education to working life. Making transition work. Paris: OECD.

Opper, S., Teichler, U., \& Carlson, J. (1990). Impacts of study abroad programmes on student and graduates. London: Jessica Kingsley Publisher.

Patria, B. (2008). Problem-based learning and graduates' competencies. International Journal of Psychology, 43(3-4), 469-470.

Tchibozo, G. (2007). Extra-curricular activity and the transition from higher education to work: A survey of graduates in the United Kingdom. Higher Education Quarterly, 61(1), 37-56. $<$ http://dx.doi.org/10.1111/j.1468-2273.2006.00337.x>

Teichler, U. (1999). Research on the relationships between higher education and the world of work: Past achievements, problems and new challenges. Higher Education, 38(2), 169-190. $<$ http://dx.doi.org/10.1023/A:1003761214250>

Vaatstra, R., \& De Vries, R. (2007). The effect of the learning environment on competences and training for the workplace according to graduates. Higher Education, 53(3), 335-357. $<$ http://dx.doi.org/10.1007/s10734-005-2413-4>

Van Hoof, H. B., \& Verbeeten, M. J. (2005). Wine is for drinking, water is for washing: Student opinions about international exchange programs. Journal of Studies in International Education, 9(1), 42-61. <http://dx.doi.org/10.1177/1028315304271480>

Vermeulen, L. (2006). The study of alumni: Professional success, commitment to the university, and the role of the academic learning environment. Rotterdam: Lemma publisher.

WZ1. (2000). Higher education and graduate employment in Europe. Kassel: Universität Gesamthochschule Kassel, Wissenschaftliches Zentrum für Berufs- und Hochschulforschung (WZ I). 
Patria, B. 